\title{
Display of Zen principles on distinctive features of Japanese business culture
}

\author{
A.A. Agekyan \\ National Research University "Higher School of Economics" \\ 17 Malaya Ordynka St., bldg. 1, Moscow, 119017, Russia \\ S.V. Shaposhnikov \\ Lomonosov Moscow State University \\ 1 Leninskie Gory St., bldg. 44, Moscow, 119234, Russia
}

The aim of the research is to determine peculiarities of Japanese business culture, which formation and development was resulted from the influence of Zen Buddhism. The relevance of issue stems from the fact that in the context of globalization it is necessary to understand cultural specificities of business cultures in order to improve and adapt them to the constantly changing business environments. The main hypothesis to be confirmed is that core principles and values of modern Japanese companies' practices to a great extent have been developed in the context of Zen, that served as a principle guideline of monks' and samurai' economic operations several centuries prior. The hypothesis will be proved through mixed methodology with the implementation of descriptive, historical and comparative analysis.

Key words: Zen Buddhism, Japanese business culture, Japan

\section{Introduction}

Being accepted as a religious and philosophical doctrine, Buddhism has significantly contributed into ideological basis of power legitimation at early stages of state formation. This process of legitimization affected the ruling house, as well as aristocratic families and immigrants from the mainland who had to justify their right to govern. Furthermore, Buddhist temples performed as economic agents being engaged in trade, legal relationship (ownership of land) and economic activities (manage granted farmlands). Consequently, Buddhism began to define specifics of Japanese style of business operations. These guidelines were later accepted and developed by the warrior class samurai, who due to the socio-political reasons were

(C) Agekyan A.A., Shaposhnikov S.V., 2019

This work is licensed under a Creative Commons Attribution 4.0 International License https://creativecommons.org/licenses/by/4.0/ 
forced to change their primary activity and became the founders of the first enterprise units.

\section{General remarks on what is Zen}

Buddhism began to attain popularity in Japan in the VI century primarily because of social and ideological circumstances. There were no beliefs of unified character in the V-VI centuries, and we can identify two main cults common for that period: cult of ancestors and cult of landscape deities. However, not all ancestral deities and families worshiping them were included in the official sacral genealogies. Moreover, most of families were not satisfied with the position occupied by their ancestral deities in the pantheon. Consequently, Shinto served as an ideological basis for local centrifugal tendencies and early Japanese state could not find an ideological support in it. Moreover, Buddhism propagated an idea of equality. This ideological framework could become the possibility for immigrants that constituted the significant part of nobility to be included in the ruling class [1. Pp. 78-79]. These factors predetermined the interest in Buddhism and contributed to the formation of several Buddhist schools. Nevertheless, in this work we will study more precisely the philosophical doctrine of Zen Buddhism, focusing on its influence on Japanese business model.

According to Zen, enlightenment can be gained only via immediate and direct intuitive understanding of reality. Zen emphasizes not faith in a savior or education, but self-effort for mental discipline. This teaching began to flourish when monk Eisai (1141-1215) founded the Rinzai School of Zen in 1191. After a while, monk Dōgen founded the Sōtō school of Zen. The latter found fertile ground in the countryside among peasants and samurai of modest means, while Rinzai School was disseminated among the upper strata of the military class [2. Pp. 9-11; 3. Pp. 119-120].

Zen is not a philosophy in the narrow sense of this word, since its system is not based on the principles of logic or analysis, no set of concepts. Zen literature does not consist of abstract statements or conceptual reasoning, it is compiled from "anecdotes", "incodemts" or "questions and answers". At the same time, it is hard to treat Zen as a religion, as far as there is no God to worship, nor ceremonial rituals to observe, and nor belief in immortal soul. Zen doctrine only points the direction giving a right to teach oneself on his/her own [4. Pp. 38-39; 5. Pp. 63, 352]. As well as the key task for a Japanese manager is to provide conditions in which workers can develop giving instructions that might seem extremely vague for western businessmen. Thus, senior management can be characterized as supervisory rather than "authoritarian".

\section{Role of Buddhism in Feudal Japan from historical and political perspectives}

Active construction of Buddhist temples at expenses of the court and donations in Japan started in 710. From the very beginning Buddhist temples performed the role of good suppliers to the markets, where it was possible to purchase not only 
foodstuffs but also writing materials and Buddhist sutras. Moreover, since the tax system has not yet been entirely developed, the main form of exploitation was labor duties, which contents were determined not only by the state but also by Buddhist temples. Buddhist temples were frequently granted lands and farmsteads. During the Heian period (794-1185) regardless of state's aspiration to distance from Buddhist temples, the latter still enjoyed number of privileges including private law on land possession and tax immunities. Furthermore, Buddhist temples became patrons of small landowners who passed to the temples land ownership but retained the right to manage the lands [1. Pp. 115-182].

One of the distinctive features of Kamakura period (1185-1333) was establishment of multipolar power system due to the interception of imperial family's political power by a new class of warriors, bushi. By that time warriors already had significant economic and political control based to a large degree on income from trade with China. However, they were trying to gain more influence asserting control over the lands of aristocracy or temples. However, Buddhist temples began to operate as economic agents even more actively. In particular, it was due to the emergence of markets that were formed nearby large monasteries and were located at the crossroads of waterways and roads. On the $2^{\text {nd }}, 12^{\text {th }}$ and $22^{\text {nd }}$ of each month these settlements turned into markets assuring economic foundations of their dwellers. Moreover, as a result of intensive economic monetization, a new category of population has appeared - moneylenders. This category was represented either by wealthy merchants of port cities or by monks, who received large incomes from their private lands as well as from congregation's offerings in monetary terms. In 1285 Buddhist and Shinto temples were allowed to transfer their lands to other temples or private persons. It was a legal recognition of the process of purchase and sale of the land [1. Pp. 195-249].

In XV-XVI centuries Buddhist temples that began to reflect primarily interests of warriors not only possessed extensive areas of land, but also participated actively in all spheres of political and economic life. In addition to the enormous material resources, temples also had large human reserves. Buddhist economic independent communities involved broad sectors of the population: peasants and citizens, craftsmen and merchants and even significant number of samurai. Moreover, Buddhist temples maintained ties with foreign merchants and built customs gates within the country [1. Pp. 286-316].

Having described the Feudal period of Japan we must conclude that during Kamakura and the first part of Muromachi (1336-1600) periods, Buddhist temples became to operate as economic agents more actively. It was exactly Buddhist priesthood who was among the first moneylenders and parties to contracts of sale and purchase. Being at the origins, Buddhist temples laid down the principal guidelines of these operations, providing a framework for implementation of bilateral and multilateral business activities. Nevertheless, starting with Oda Nobunaga (1534-1582) actual governors and shoguns began to implement measures limiting political and economic influence of Buddhist temples eliminating the system of customs gates and strictly controlling temples' properties. 


\section{Zen and the Samurai}

For historical reasons, Zen Buddhism was initially embraced by the military class as an agency of cultural advancement and political consolidation. Hence, Kamakura, being the seat of feudal government and militaristic regime became the center of Zen [5. Pp. 29, 63].

Spirit of Zen was in compliance with the intended character of samurai's life. The main common points between Zen and Bushido are aloofness from worldly affairs, exhortation to the willpower, virility and simplicity. From a religious perspective, Zen Buddhism teaches samurai not to leave the chosen path but to follow it expressing the will power and not looking backward. From a philosophical point of view, Zen was embraced by samurai with its apathetic attitude towards life and death. However, the main reason for samurai' favor towards Zen was its practicality coupled with asceticism. Samurai, constantly facing the death, has to be free from attachments to various objects and life in general. Moreover, Zen addresses the issue of death without ritualism or sophisticated learning. Zen teaches that in order to be ready to give life, it is necessary to attain state of "no-mind-ness" (mushin), which is a state of mind free of dualities and concerns about death or immortality [5. Pp. 30, 61-94].

Nevertheless, in the beginning of XVII century changing living conditions in Japan forced Shinto and Buddhist monks, samurai and peasants to alter their habitual foundations and traditions. Most of them became merchants. As a result of policy known as heinō bunri (separation of samurai from peasants) pursued by the second "great unifier" Toyotomi Hideyoshi, part of samurai class remained in the villages. They began to be called gōshi (rural samurai) and were deprived from the right to carry a sword, which meant deprivation of their former social status. Having rather good material base, they began to be engaged in trade. Moreover, in the beginning of the Edo period (1600-1868) powerful feudal lords daimyōs, who were promoted from the ranks of samurai, have been forced to concentrate on economic activities. This tendency was mainly common for daimyōs who were in opposition to Tokugawa Ieyasu. Various repressive measures were applied to them (reduction of land properties, compulsory military service). However, the most burdensome duty was construction and repair works in Edo, supply of workforce and materials costs. Consequently, this led to the impoverishment of their principalities, emphasizing the necessity of new sources of income which resulted in alteration of their main field of activities and formation of firms [1. Pp. 408-576].

One remarkable fact deserving notice at this point is that samurai who were forced to start performing trade operations began to compile the code of conducts. These rules referred not only to the range of responsibilities, but also to the rules of conduct and relationships between employees. Such example is a House code of 1720 compiled by Takatoshi Hachirōbei, the founder of Mitsui Group. It stated that new employees had to show piety to long-working and elderly people and peace in the house could be reached only when master and the servants are in harmony $[1$. Pp. 485-496; 6. Pp. 5-6, 13]. 
One of the founders of the leading financial and industrial corporation Sumitomo Group is Masamoto Sumitomo (1585-1652). He was a Buddhist monk who took off monk's robe and opened a shop selling books and medicines when persecutions started. In a consequence, production and sell of high quality copper has become the main source of income. Masatomo described principles of business conduct in Monjuin Shiigaki (Founder's Precepts) laying the foundations for several charters of Sumitomo family compiled in the XVIII century [1. Pp. 497-501].

Charter regulating operations on the copper mine Besshi was completed in 1721 and consisted of 13 rules. The rule number 12 stated that while addressing the issue of prices it is worth to take into account collegial decision. Such decision-making process is typical for many modern Japanese enterprises. According to paragraph 13 it is necessary to implement vocational training, which would allow in case of productive needs to use workers in different positions, as far as employees would have an experience of work in different production sites. This practice of "personnel reshuffle" is common for modern Japanese companies as well [1. P. 501].

Consequently, Zen Buddhism being religious and philosophical teaching was embraced by samurai as a framework of ideas allowing them to reconcile with their social duties. However, due to the historical circumstances they were forced to change their major field of activities. By that time, when samurai began to open their first shops and began to be engaged in their first economic operations, Buddhism has already had centuries of experience in the sphere of commodity and money relations. Hence, it could serve as a guidance of principles of labor organization.

\section{Display of Zen principles on distinctive features of Japanese business culture}

In this paragraph we will distinguish features of Japanese business culture that were affected by principles of Zen Buddhism.

Meaning of work. Work in Japan is considered to be an activity that adds meaning to life. This is related to the fact that in Japanese society person's status in company refers to the position in workplace as well as to the social status outside the company. However, this perception of work is also emphasized by the Buddhist view that work is a spiritual discipline leading to the achievement of Nirvana. For Zen monks there is no work beneath their dignity as they believe in its holiness [4. Pp. 18; 7. Pp. 71].

We can draw a parallel between this attitude of Buddhist monks and a Japanese practice called Jinji ido or re-distribution of personnel as a way to help people develop their careers and keep from stagnant. As a result of this "personnel reshuffle" an employee can be assigned to various positions in various office locations. Furthermore, traditionally job boundaries in Japanese companies were not clearly defined. Employees were not provided with job descriptions since they were supposed to work flexibly beyond their job responsibilities and subunits. This management style that pays particular attention to multi-skilled workers is called Genba Shugi [8. P. 147].

Role of human relationship. The impact of Zen Buddhism is also reflected in the role of human relationships as far as it underlines the significance of tolerance 
and spiritual equality, respect for elders and loyalty. In terms of business, it determines community characteristics of Japanese business model, which core principles are concepts of reciprocity and harmony. To maintain them, subordinates should be loyal to their superiors and superiors should be concerned with the well-being of subordinates [9. P. 27]. Furthermore, the main aim of negotiations is to reach consensus by making each member to be involved in this process. This emphasizes equality of people taking part in the decision-making process and significance of their opinions. This bottom-up decision making process is called ringi seido, that defines the procedure of particular idea's discussion, confirmation carried out by all those who might be affected by the decision [10. P. 50].

Maintenance of long-term relations also has several reflections on the way how Japanese managers treat their customers and partners. Namely, aftersales personal visits and a culture of giving gifts can be mentioned. These practices express the desire not to be limited by business interactions but to establish more confidential relations.

Japanese attitude towards the contract and significance of circumstances. In Japanese business culture trust is the most essential part. Thus, it is not necessary to sign detailed contracts. Even if there is a written contract, content is very simple and brief. It reflects Buddhist perception of life according to which reality is inconstant. In such conditions, human kind is expected to be flexible in order to be able to adapt to occurring changes. The only way to attain flexibility is to get rid of attachments. Words, themselves, are attached to certain conditions. Hence, they become meaningless as soon as they are taken out of their original context. Furthermore, words tend to detach from certain contexts and turn into conception. Whereas, conceptualization is exactly what Zen Buddhism strives to avoid [11. P. 6].

Contract is considered to serve as a formal testimony of long-term trust-based relationships established rather than an instrument used by parties to designate mutual duties and obligations. It enables parties to sit down repeatedly at the negotiating table if required, underlining the significance of long-term relations to be maintained rather than focusing on short-term intermediate results.

Such an attitude towards the contract also reflects Zen Buddhists' view on the significance of words and sacred sutras. It is considered that true and sincere attitude cannot be expressed through words as they can lose their practical value while they cannot correspond to the actual facts or conditions [4. Pp. 40, 59-61].

Importance of silence. Being verbose and argumentative is not typical for Japanese business people who give preferences to facts without emotional or conceptual dimensions. Triviality of words is related to the fact that conceptual contexts determine their meanings. However, silence is not constrained by such boundaries and truth can be comprehended only in silence [11. P. 7]. It specifies significance of silence that has reflections on Japanese business culture, namely, on haragei or the way of conducting of negotiations during which expanded context is gained from a surrounding environment. In case of controversial issues, appealing to silence is a way to release the tension and enable parties to continue negotiations. Moreover, silence can express an intuitive understanding between the interlocutors. The meaning of 
the context and silence as a communicative tool may vary depending on the situation. Hence, non-verbal communication adds value to the verbal communication.

Self-control and self-discipline. Ability to conceal personal reaction, emotions and feelings not expressing them in words, testifies that in the system of priorities one's state of mind is less significant than the state of society. This is a display of self-control and self-discipline.

Adherence to self-discipline is indispensable in aspiration for perfection. Deliverance as well as purification can be attained only when person is conscious of every thought, word and act [2. P. 24].

Self-discipline is expected to be one of the main characteristics of Japanese managers. Being a part of a company, the Japanese employee should be guided by company's strategy and cultural value and has to follow the instructions of superior not subjecting them to doubt or controversy. Furthermore, such peculiarities of Japanese business negotiations as minimal body language, sitting in a formal upright posture, not expressing any reactions or emotions can be also interrelated with self-control.

Emphasis on observation and learning. According to the Zen doctrine, truth and essential ideas can be grasped only by seeking for a new point of view that was unavailable earlier and can expand the boundaries of consciousness. Acquiring a new viewpoint is called satori. Satori is an outcome of simplest possible experience, of an insignificant event, after which person realizes that everything he wants to see and comprehend always was nearby [4. P. 88, 92].

This attitude reflects the focus of Japanese companies on observation and learning based on experience. For instance, when it comes to the development of new product companies use information gained from their customers and their reviews. Here we can as well make a reference to the Japanese-style production practice kaizen that denotes not only endless improvement but also day-to-day accumulation of the results by virtue of such practices as quality control circles. Being integrated into the Toyota production system (TPS or Lean production) this accumulation aims at facilitating higher levels of productivity and quality. In general, practice-oriented inductive ways of conducting research and development are more inherent to Japanese people than theory-oriented deductive ways [10. P. 260].

Another example illustrating emphasis on observation and learning is the Japanese problem solving system that is sometimes abbreviated as Ho (hokoku, or report), Ren (renraku, or contact) and So (sodan, or consult). This system encourages not only collective decision-making, mutual trust and cooperation in the group, but also prevents re-occurrence of the problem in the future.

\section{Conclusion}

The analysis shows that cultural specificity of Zen Buddhism reflects strongly on main features of Japanese management culture, defining long-term planning, participative management, trust and interdependence, emphasize on teamwork and cooperation as traditional characteristics of Japanese style management. 


\title{
REFERENCES
}

[1] Zhukov A.E. History of Japan. From ancient times till 1868. Moscow: Institut vostokovedeniya RAN, 1998. (In Russ.)

[2] Senzaki N. Buddhism and Zen. New York: Philosophical Library, 1953.

[3] Kim Y.C. Oriental thought. An Introduction to the philosophical and religious thought of Asia. Springfield: Charles C. Thomas Publisher, 1973.

[4] Suzuki D.T. An introduction to Zen Buddhism. New York: First Evergreen Black Cat Edition, 1964.

[5] Suzuki D.T. Zen and Japanese culture. Princeton: Bollingen Paperback printing, 1973.

[6] Horie Y. The role of the ie (家 - house) in the economic modernization of Japan // Memories of the Faculty of Economics in the Kyoto University. 1966. No. 36(1). Pp. 5-6.

[7] Alston J.P., Isao T. Japanese business culture and practices. A guide to twenty-first century Japanese business. Bloomington: iUniverse, Inc., 2005.

[8] Fukui N. Changes in performance appraisal in Japanese companies // Norio K. Japanese management in change. Tokyo: Springer Japan, 2015. Pp. 141-158.

[9] Tanaka $K$. The perceived development and unperceived decline of corporate governance in Japan // Norio K. Japanese management in change. Tokyo: Springer Japan, 2015. Pp. 17-34.

[10] Bird A. Encyclopedia of Japanese business and management. New York: Routledge; 2002.

[11] Gloria G. Japanese cultural values in business relationships. Madrid: Elcano Royal Institute, 2015 (cited 2019 July 7). URL: https://www.coursehero.com/file/42106637/ ARI29-2015-Garcia-Japanese-cultural-values-business-relationshipspdf/

Научная статья

\section{Влияние дзэн-буддистского мировоззрения на бизнес-культуру Японии}

\author{
А.А. Агекян \\ Национальный исследовательский университет «Высшая школа экономики» \\ Россия, 119017, Москва, ул. Малая Ордынка, д. 17, стр. 1,
}

\section{С.В. Шапошников}

Московский государственный университет имени М.В. Ломоносова Россия, 119234, Москва, Ленинские горы, д. 1, стр. 44

Цель данной работы - определение особенностей японской бизнес-культуры, становление и развитие которых обусловлено влиянием дзэн-буддизма. Актуальность проблемы обусловлена тем, что в условиях глобализации необходимо понимать культурные предпосылки формирования бизнес-процессов, чтобы совершенствовать и адаптировать их к постоянно меняющимся экономическим условиям. Автор работы полагает, что основные принципы и ценности управленческой практики японских компаний в значительной степени были разработаны в контексте дзэн-буддизма, который определял особен- 
ности экономических операций монахов и самураев в прошлом. Данная гипотеза будет подтверждена применением описательного, исторического и сравнительного методов исследования.

Ключевые слова: дзэн-буддизм, бизнес-культура Японии, Япония

Информация об авторах / Information about the authors

Агекян Ани Акоповна, магистрант Школы востоковедения факультета мировой экономики и мировой политики Национального исследовательского университета «Высшая школа экономики». E-mail: aaagekyan@edu.hse.ru

Шапоиников Сергей Вячеславович, кандидат экономических наук, доцент Высшей школы бизнеса МГУ имени М. В. Ломоносова.

Ani Agekyan, master student in National Research University Higher School of Economics Faculty of World Economy and International Affairs, School of Asian Studies. E-mail: aaagekyan@edu.hse.ru

Sergey Shaposhnikov, PhD in Economics, Associate Professor at Business School Lomonosov Moscow State University. E-mail: shaposhnikov@mgubs.ru

\section{Для цитирования / For citation}

Агекян А.А., Шапошников С.В. Влияние дзэн-буддистского мировоззрения на бизнес-культуру Японии // Вестник Российского университета дружбы народов. Серия: Всеобщая история. 2019. Т. 13. № 3. С. 213-221.

Agekyan A. A., Shaposhnikov S. V. Display of Zen principles on distinctive features of Japanese business culture // RUDN Journal of World History. 2019. Vol. 13. No. 3. Pp. 213-221.

Рукопись поступила в редакцию / Article received:

11.08.2019 